\title{
Content of Glutathione and Vitamin C in the Liver of Rats Exposed to Dimethoate and Pyrantel Tartrate
}

\section{A. SPODNIEWSKA, A. ZASADOWSKI}

Division of Veterinary and Environmental Toxicology, Department of Pathology and Pharmacology, Faculty of Veterinary Medicine, University of Warmia and Mazury in Olsztyn, Poland

Received March 1, 2007

Accepted June 11, 2008

\begin{abstract}
Spodniewska A., A. Zasadowski: Content of Glutathione and Vitamin C in the Liver of Rats Exposed to Dimethoate and Pyrantel Tartrate. Acta Vet. Brno 2008, 77: 355-362.

The study was undertaken to examine the effect of oral administration of dimethoate (Bi 58 Nowy) and/or pyrantel tartrate on the concentration of glutathione (GSH) and vitamin $\mathrm{C}$ in rat liver. Rats of Group I were administered pyrantel tartrate at a dose of $85 \mathrm{mg} / \mathrm{kg} \mathrm{b}$.w. at a twoweek interval, while the animals of Group II received Bi 58 Nowy (38\% dimethoate) at a dose of $25 \mathrm{mg} / \mathrm{kg}$ b.w. for 28 days, and animals of Group III received both compounds together as described above. Pyrantel tartrate was found to increase the concentration of glutathione in the liver, whereas the content of vitamin $\mathrm{C}$ oscillated around values reported for the control. After a 28-day exposure to dimethoate (Bi 58 Nowy), except for the $6^{\text {th }}$ hour after intoxication, the content of GSH was observed to increase and significant differences $(p \leq 0.05)$ occurred after days 3 and $14(p \leq 0.01)$. The concentration of vitamin $\mathrm{C}$ in liver homogenates after dimethoate administration was decreased compared to the control until day 3 . An increase was then observed continuing until the end of the experiment. In animals receiving both compounds, except for day 7 , the concentration of vitamin $\mathrm{C}$ was slightly decreased. The administration of pyrantel tartrate before dimethoate (Bi 58 Nowy) only in some time intervals was found to reduce the intensity of changes evoked by the exclusive administration of insecticide. It may suggest that not in all cases of mixed intoxications, intensification should be expected in changes of the variables analyzed.
\end{abstract}

Dimethoate, pyrantel tartrate, glutathione, vitamin $C$, rat

Amongst the threats posed by chemical substances, special attention should be paid to hazards linked to the use of pesticides (Jeyaratnam 1990; Steenland et al. 1994, 1996). Due to their extensive use, the problem of their toxic interactions with various compounds, including drugs, becomes of key importance in terms of both biological and therapeutic effects observed as well as mechanisms affecting this phenomenon.

Organophosphate (OP) insecticides, including dimethoate (O,O-dimethyl S-methylcarbamoylmethyl phosphorodithioate), due to their rapid degradation in the environment, are one of the major and most extensively used pesticides in agriculture (Pruett 1996; LUIS 1997). The mechanism of the toxic action of dimethoate (similar to other OP compounds) is one of inhibiting the acetylcholinesterase activity. Recent studies have also demonstrated that organophosphate insecticides induce oxidative stress through generation of free radicals and induction of lipid peroxidation (Altuntas et al. 2003; Abdollahi et al. 2004; Yarsan and Cakir 2006).

Pyrantel tartrate (trans-1, 4, 5, 6-tetrahydro-1-methyl-2-[2-(thienyl)-vinyl] pyrimidine) is a commonly used, effective agent against intestinal nematodes in horses and pigs (Valdez et al. 1995; Lyons et al. 2007). It exhibits a strong agonistic effect on nicotine receptors (AChRs) and capacity for blocking open ion channels linked with AChRs (Rayes et al. 2001).

Due to the significant role of oxidative stress in the toxic action of pesticides and other chemical compounds (including drugs) (Yarsan et al. 1999; Altuntas et al. 2004;

Address for correspondence:

Anna Spodniewska

Division of Veterinary and Environmental Toxicology

Department of Pathology and Pharmacology, Faculty of Veterinary Medicine

University of Warmia and Mazury in Olsztyn

E-mail: anspod@uwm.edu.pl

Oczapowskiego 14, 10-719 Olsztyn, Poland

http://www.vfu.cz/acta-vet/actavet.htm 
Kalender et al. 2004), the aim of the present paper was to determine the content of vitamin $\mathrm{C}$ and glutathione (GSH) in the livers of rats exposed to single or combined intoxication with dimethoate (Bi 58 Nowy) and pyrantel tartrate.

This paper is a part of the research project concerning dimethoate and pyrantel interaction and their effect on the oxidative status of rats.

\section{Materials and Methods}

The experiment was conducted with Bi 58 Nowy (BASF, Germany), which contains $38 \%$ of pure dimethoate (O,O-dimethyl S-N-methyl carbamoyl methyl phosphodithioate), according to the manufacturer's instructions. Pyrantel tartrate, containing $100 \%$ of pure compound, was obtained from the Biowet-Gorzów Pharmaceutical Company, Poland.

Studies were carried out on 120 male Wistar rats (initial body weight of $180 \pm 10 \mathrm{~g}$ ) from the Animal Breeding Centre in Brwinów near Warsaw. The animals were housed under standard laboratory conditions (i.e. $12 \mathrm{~h}$ light/ dark cycle, ambient temperature of $22 \pm 1{ }^{\circ} \mathrm{C}$, air humidity $70 \pm 10 \%$ ) and allowed free access to standard laboratory rat chow and water.

Rats were divided into three experimental (I - III) and one control (C) groups, 30 animals per group. Animals of Group I received pyrantel tartrate in water suspension by gavage at a dose of $85 \mathrm{mg} / \mathrm{kg} \mathrm{b}$.w. on the $14^{\text {th }}$ and $28^{\text {th }}$ day of the experiment from the beginning of dimethoate intoxication. Animals of Group II were given dimethoate (Bi 58 Nowy) at a concentration of $88.6 \mathrm{mg} / \mathrm{dm}^{3}$ in drinking water for 28 days. Each animal received about 15.5 $\mathrm{mg} / \mathrm{kg}$ of dimethoate daily, which constitutes $1 / 25$ of $\mathrm{LD}_{50}(25 \mathrm{mg} \mathrm{kg} \mathrm{b.w.).}$

Rats in Group III received both dimethoate (Bi 58 Nowy) and pyrantel tartrate at the doses and the regime of administration as in the above groups (I and II). The control group (C) received standard chow and water $a d$ libitum only.

The experiments conducted on rats followed the provisions of the "Act on Animal Protection" and the recommendations of the Local Ethical Committee for Animal Experiments, University of Warmia and Mazury in Olsztyn (No 49/N 2002).

The rats were sacrificed at different times, i.e. 6 and 24 hours, and 3, 7 and 14 days after the last administered dose of the compounds under study, and their livers were excised to determine glutathione and vitamin $\mathrm{C}$ concentrations.

The content of vitamin C was determined using the method of Kyaw modified by Rutkowski et al. (2002) with the use of the phosphotungstic reagent.

The concentration of glutathione (GSH) was assayed with the colorimetric method for detection of thiolic groups using the Ellman reagent DTNB (5,5'-dithiobis-2-nitrobenzoic acid) (Ellman 1959; Griffin et al. 1982, 1983).

The data were analyzed statistically by one-way analysis of variance (ANOVA) followed by NewmanKeuls test. All results were expressed as mean \pm SEM. A difference was considered significant at $p \leq 0.05$ and $p \leq 0.01$.

\section{Results}

Concentrations of glutathione and vitamin $\mathrm{C}$ in the hepatic tissue of rats are presented in Tables 1 and 2 .

Administration of pyrantel tartrate to rats at the dose of $85 \mathrm{mg} / \mathrm{kg}$ b.w. (Group I) elevated the concentration of GSH compared to the control group, and the increase continued throughout the entire experimental period (Table 1). A significant increase occurred after the $6^{\text {th }}$ hour and after the $3^{\text {rd }}$ day $(p \leq 0.05)$. In rats of Group II, receiving $25 \mathrm{mg} / \mathrm{kg} \mathrm{b} . \mathrm{w}$. of dimethoate for 28 days, a 7\% decrease in the level of GSH was observed only after the $6^{\text {th }}$ hour, but that change was not significant. In the subsequent analytical periods, a gradual increase was observed in the value of this variable compared to the control group. On days 3 and 14, the increase was significant ( $p \leq 0.05$ and $p \leq 0.01$, respectively). Changes in the GSH concentration in the group of animals intoxicated with dimethoate and pyrantel (Group III) were similar to those reported for rats from gr. II. A significant decrease $(11.9 \%)$ occurred after the $6^{\text {th }}$ hour, whereas an increase $(13.8 \%)$ occurred after the $3^{\text {rd }}$ day of intoxication $(p \leq 0.01)$.

The content of vitamin $\mathrm{C}$ in rats receiving pyrantel tartrate (Group I) oscillated around control values with a slight downward tendency after the $6^{\text {th }}$ hour and $14^{\text {th }}$ day (Table 2$)$. After dimethoate administration (Group II), the concentration of vitamin C in liver homogenates 
Table 1. Glutathione (GSH) concentration in the liver of rats exposed to dimethoate (Bi 58 Nowy), pyrantel tartrate and dimethoate (Bi 58 Nowy) and pyrantel tartrate $(\mu \mathrm{g} / \mathrm{g} \text { fresh tissue })^{\mathrm{a}}$

\begin{tabular}{|c|c|c|c|c|c|}
\hline \multirow{2}{*}{$\begin{array}{l}\text { Group of animals } \\
(\mathrm{n}=6)\end{array}$} & & \multicolumn{4}{|c|}{ Time after intoxication } \\
\hline & 6 hours & 24 hours & 3 days & 7 days & 14 days \\
\hline $\begin{array}{c}\mathrm{C} \\
\text { (Control) }\end{array}$ & $\begin{array}{l}12.94 \\
\pm 0.30\end{array}$ & $\begin{array}{c}11.53 \\
\pm 0.35\end{array}$ & $\begin{array}{c}11.42 \\
\pm 0.46\end{array}$ & $\begin{array}{r}13.05 \\
\pm 0.25\end{array}$ & $\begin{array}{c}11.62 \\
\pm 0.36\end{array}$ \\
\hline $\begin{array}{c}\text { I } \\
\text { (Pyrantel tartrate) }\end{array}$ & $\begin{array}{r}14.73 \\
\pm 0.30 \\
\end{array}$ & $\begin{array}{r}12.63 \\
\pm 0.33 \\
\end{array}$ & $\begin{array}{r}12.86 \\
\pm 0.19 \\
\end{array}$ & $\begin{array}{r}13.87 \\
\pm 0.20 \\
\end{array}$ & $\begin{array}{r}13.05 \\
\pm 0.51 \\
\end{array}$ \\
\hline $\begin{array}{c}\text { II } \\
\text { (Dimethoate) }\end{array}$ & $\begin{array}{r}12.03 \\
\pm 0.47 \\
\end{array}$ & $\begin{array}{r}12.25 \\
\pm 0.33 \\
\end{array}$ & $\begin{array}{r}12.65 \\
\pm 0.18 \\
\end{array}$ & $\begin{array}{r}14.13 \\
\pm 0.55 \\
\end{array}$ & $\begin{array}{r}13.61 \\
\pm 0.45 \\
\end{array}$ \\
\hline $\begin{array}{c}\text { III } \\
\text { (Dimethoate }+ \\
\text { pyrantel tartrate) }\end{array}$ & $\begin{array}{r}11.39 \\
\pm 0.39\end{array}$ & $\begin{array}{l}12.49 \\
\pm 0.34\end{array}$ & $\begin{array}{l}13.12 \\
\pm 0.28\end{array}$ & $\begin{array}{l}13.97 \\
\pm 0.28\end{array}$ & $\begin{array}{l}12.84 \\
\pm 0.41\end{array}$ \\
\hline $\begin{array}{l}\text { Statistical } \\
\text { differences }\end{array}$ & $\begin{array}{l}\mathrm{P}_{\mathrm{C}-\mathrm{I}}<0.05 \\
\mathrm{P}_{\mathrm{C}-\mathrm{III}}<0.01 \\
\mathrm{P}_{\text {I-II,III }}<0.01\end{array}$ & & $\begin{array}{l}\mathrm{P}_{\mathrm{C-I,II}}<0.05 \\
\mathrm{P}_{\mathrm{C}-\mathrm{III}}<0.01\end{array}$ & & $\mathrm{P}_{\text {C-II }}<0.01$ \\
\hline
\end{tabular}

a - values expressed as mean \pm SEM of 6 rats

Table 2. Vitamin C concentration in the liver of rats exposed to dimethoate (Bi 58 Nowy), pyrantel tartrate and dimethoate (Bi 58 Nowy) and pyrantel tartrate $\left(\mu \mathrm{g} / \mathrm{g}\right.$ fresh tissue) ${ }^{\mathrm{a}}$

\begin{tabular}{|c|c|c|c|c|c|}
\hline \multirow{2}{*}{$\begin{array}{c}\text { Group of animals } \\
(\mathrm{n}=6)\end{array}$} & \multicolumn{4}{|c|}{ Time after intoxication } \\
\cline { 2 - 6 } & 6 hours & 24 hours & 3 days & 7 days & 14 days \\
\hline C & 220.99 & 258.94 & 290.95 & 249.92 & 255.21 \\
(Control) & \pm 13.77 & \pm 17.10 & \pm 4.11 & \pm 9.78 & \pm 14.41 \\
\hline I & 209.33 & 268.73 & 300.52 & 261.23 & 245.64 \\
(Pyrantel tartrate) & \pm 11.12 & \pm 7.52 & \pm 6.27 & \pm 8.01 & \pm 11.49 \\
\hline II & 205.63 & 238.37 & 257.95 & 279.29 & 266.93 \\
(Dimethoate) & \pm 4.15 & \pm 18.19 & \pm 6.09 & \pm 20.61 & \pm 3.94 \\
\hline III & 206.47 & 249.48 & 273.02 & 273.13 & 249.21 \\
(Dimethoate + & \pm 23.37 & \pm 21.91 & \pm 14.04 & \pm 20.01 & \pm 11.07 \\
pyrantel tartrate) & & & $\mathrm{P}_{\text {C-II }}<0.05$ & $\mathrm{P}_{\text {C-II }}<0.05$ & \\
\hline Statistical & & $\mathrm{P}_{\text {I-II }}<0.05$ & & \\
differences & & & & \\
\hline
\end{tabular}

a - values expressed as mean \pm SEM of 6 rats

was lower compared to controls up to day 3 (inclusive), and its increase continued until the end of the experiment. Significant differences $(p \leq 0.05)$ occurred on day 3 and 7 after exposure (11.3\% and $11.8 \%$, respectively). As compared to the animals exposed to pyrantel (Group I), a significant decrease was reported 3 days after the application of the last dose of the compound. In rats intoxicated with both compounds (Group III), the content of ascorbic acid was slightly reduced compared to control, except for day 7 . On day 7 of the experiment, the concentration of vitamin $\mathrm{C}$ was $9 \%$ higher than that found the control, but this increase was not significant.

\section{Discussion}

Glutathione and vitamin $\mathrm{C}$ constitute the first line of antioxidant defence in the course of ischemia-reperfusion damage (Altuntas at al. 2002).

Glutathione (GSH) ( $\gamma$-glutamyl-L-cysteinylglycine) is indispensable for maintaining the redox status and preventing the effects of oxidative stress (Parke and Piotrowski 1996; Dringer 2000; Suntres 2002). Vitamin C (ascorbic acid) is the main water-soluble 
antioxidant vitamin capable of directly scavenging free radicals (hydroxyl, superoxide and singlet oxygen) (Patra et al. 2001; Molyneux et al. 2002).

An increase in the content of GSH was observed over the entire experimental period in the liver of rats intoxicated with pyrantel tartrate at the dose of $85 \mathrm{mg} / \mathrm{kg}$ b.w. administered twice in a two-week interval. In the available literature no data were found on the effect of anthelminthic agents on the concentration of GSH in tissues of humans and animals, however, the elevated content of GSH may be linked with intensification of reduction processes of the oxidized form of glutathione (GSSG) as a result of enhanced activity of enzymes participating in glutathione metabolism, mainly GR, which has been corroborated by the studies of other authors (Parke 1991; Parke and Piotrowski 1996).

We found that both the exclusive exposure of animals to dimethoate (Group II) as well as combined intoxication with dimethoate and pyrantel tartrate (Group III) triggered a decrease in the GSH content in rat livers only in the first period after intoxication (up to the $24^{\text {th }} \mathrm{h}$ ). However, a greater decrease was observed after mixed intoxication (Group III). Corresponding results were obtained earlier by Wysocki and Zasadowski (2005) who used a concentrate of technical dimethoate and pyrantel embonate. They observed a decrease in the concentration of hepatic GSH in the first period of the study; however, that decline lasted longer (up to $12 \mathrm{~h}$ ) after exclusive administration of dimethoate. These results are consistent with the findings of other authors referring to administration of various pesticides (Łukaszewicz-Hussain and Moniuszko-Jakoniuk 2003). Sharma et al. (2005) administered various doses of dimethoate $(0.6,6$ and $30 \mathrm{mg} / \mathrm{kg} \mathrm{b.w})$ to rats for 30 days, and found a significant decline in the GSH content both in the liver and brain of the animals after doses of 6 and $30 \mathrm{mg} / \mathrm{kg}$. Subchronic exposure to dimethoate caused a decrease in the GSH level and, simultaneously, an enhanced activity of GST and GR in the liver and brain of the animals. As a result of an 8-week oral administration of chlorpyrifos (at a dose of $13.5 \mathrm{mg} / \mathrm{kg}$ b.w.) to rats, Goel et al. (2005) observed a decreased level of hepatic GSH. They suggested that under oxidative stress, the content of GSH used by glutathione-dependent enzymes decreases. Other authors (Ahmed et al. 2000) imply that, apart from the above-mentioned mechanism of action, the reduced level of GSH may also be caused by its direct participation in free radical reactions initiated by organophosphate compounds (malathion). GSH may act independently by evoking detoxication of active forms of oxygen, e.g. $\mathrm{H}_{2} \mathrm{O}_{2}$, or reduction of lipid peroxidation. Sivapiriya et al. (2006) demonstrated that the administration of dimethoate and ethanol to mice induced lipid peroxidation and reduced the GSH pool. Depletion of GSH stores in the liver supports the hypothesis that reactive oxygen species generated during dimethoate and ethanol metabolism lead to oxidation of GSH and lipid peroxidation, and are responsible for their complex toxic effect. These authors also assume that a decrease of hepatic GSH and GST under acute intoxication with dimethoate and ethanol may initially lead to losses of both of those variables from the liver to plasma. Moreover, GSH - a direct scavenger of free radicals - constitutes a substrate for GPx and GST. In their study, the activity of these enzymes was also reduced. Thus, this can be ascribed to the unavailability of reduced glutathione.

The reduction in the level of GSH observed in the reported study, as well as in studies by other authors can be linked with its participation in detoxication of the compound itself as well as reactive oxygen species generated upon the pro-oxidative action of pesticides and as a result of its use by glutathione-dependent enzymes.

The results obtained in the current study, in which an increase (by $6-17 \%$ compared to control) was observed in the content of GSH in the liver $24 \mathrm{~h}$ after intoxication of rats with dimethoate, as well as dimethoate and pyrantel tartrate, confirm the previous investigations of Wysocki and Zasadowski (2005), who observed an increased level of hepatic GSH $12 \mathrm{~h}$ after both single and mixed intoxication of the rats with dimethoate at a dose of $1 / 25$ 
$\mathrm{LD}_{50}$ and pyrantel embonate at a dose of $1 / 2 \mathrm{LD}_{50}$. Similarly, John et al. (2001) having administered the rats both dimethoate $(0.03 \mathrm{mg} / \mathrm{kg}$ b.w. $)$ and malathion $(0.13 \mathrm{mg} / \mathrm{kg} \mathrm{b.w.})$ per os, reported an increase in the blood level of GSH on day 3 after intoxication. The increased level of GSH may be attributed to intensification of its synthesis in hepatic cells, since a rapid activation was observed in the case of mechanisms to compensate for the GSH loss. They involve intensification of de novo synthesis processes $(\gamma$-glutamylcysteine synthetase and glutathione synthetase) of that tripeptide, and the enhancement of the reproduction efficiency of its reduced form from the oxidized form (Dringer 2000; Pastore et al. 2003).

Pyrantel tartrate administered to rats twice at the dose of $85 \mathrm{mg} / \mathrm{kg} \mathrm{b}$.w. did not cause any significant changes in the content of ascorbic acid in the liver. Throughout the experimental period, vitamin $\mathrm{C}$ concentration oscillated around control values. In an earlier study by Spodniewska and Zasadowski (2006), pyrantel embonate administered to rats at a dose of $1 / 5 \mathrm{LD}_{50}$ for 3 consecutive days, was demonstrated to decrease the concentration of ascorbic acid in the final period of the experiment, i.e. on day 7 and 14 , whereas the administration of pyrantel embonate at the dose of $1 / 2 \mathrm{LD}_{50}$ on day 14 and 28 of the experiment was observed to increase the vitamin $\mathrm{C}$ content in the liver $3 \mathrm{~h}$ after exposure. Since no data were found in the available literature on the effect of anthelminthic agents on the level of vitamin $\mathrm{C}$ in tissues of animals, an analysis of the works of the above-mentioned authors suggests that the differences in the results obtained may be due to the application of various forms (embonate, tartrate), doses and periods of pyrantel administration.

Once the rats were intoxicated with dimethoate in the form of a Bi 58 Nowy preparation, a decrease in vitamin $\mathrm{C}$ concentration was observed till the $3^{\text {rd }}$ day of the experiment (inclusive). A similar tendency was observed after mixed intoxication with Bi 58 Nowy and pyrantel tartrate, however, the changes were less intensive. The diminished concentration of vitamin $\mathrm{C}$ may indicate intensification of oxidative stress, generation of free radicals, and damage to the cellular membrane of hepatocytes as affected by the compounds applied in the experiment. A decreased vitamin $C$ concentration in the liver was previously reported in a study by Spodniewska and Zasadowski (2006) after intoxication of rats with dimethoate (a technical concentrate) at a dose of $1 / 10 \mathrm{LD}_{50}$. However, the decrease occurred from the $12^{\text {th }}$ hour till the $7^{\text {th }}$ day, which was not observed after 28 -day intoxication with a dose of $1 / 25 \mathrm{LD}_{50}$. Łukaszewicz-Hussain and Moniuszko-Jakoniuk (2003), when administering various doses of chlorfenvinfos to rats $\left(0.02,0.1\right.$ and $\left.0.5 \mathrm{LD}_{50}\right)$, also observed a decrease in vitamin $\mathrm{C}$ level in serum, however, the decrease appeared to be greater after administration of lower doses of the pesticide. A reduced level of vitamin $\mathrm{C}$ in the testicles was also reported by Narayana et al. (2005) after intoxication of rats with methylparathion. Studies by Ikeda et al. (2003) demonstrated that paraquat administered to rats intraperitoneally at a dose of $50 \mathrm{mg} / \mathrm{kg}$ b.w. significantly decreased the level of ascorbic acid in the lungs, but not in the serum, liver or kidneys. This was explained by the authors by the utilization of vitamin $\mathrm{C}$ as a scavenger of free radicals directly at the site of the toxic action of paraquat. The available literature provides only sparse reports on the content of vitamin $C$ in tissues of animals after exposure to organophosphate pesticides. Based on the authors' current investigations as well as scanty reference data, it should be assumed that a decrease in the vitamin $\mathrm{C}$ content of liver occurs as a result of the activation of antioxidant systems by the organisms in defence against reactive oxygen species generated upon the activity of the compounds used.

The observed decrease in vitamin $\mathrm{C}$ concentration in the liver may be also explained by its utilization for the regeneration of $\alpha$-tocopherol, one of the elements of non-enzymatic antioxidant defence, whose content decreases under conditions of oxidative stress, which has been suggested by Meister (1992) and Ficek (1997). The decrease in the ascorbic acid content could also be due to the direct impact of the compounds examined (dimethoate and 
pyrantel) on the synthesis of vitamin $\mathrm{C}$ and metabolic pathways that require its presence. Similar suggestions were also postulated by Padh (1991) and Sauberlich (1994) who described the biochemical functions of vitamin $\mathrm{C}$ in the organisms.

The increase in vitamin $\mathrm{C}$ levels in rat livers after exposure to both the Bi 58 Nowy and the Bi 58 Nowy with pyrantel was observed in the final period of the experiment, i.e. after day 7 . The elevated concentration of vitamin $C$ could be due to the elimination of the compounds examined (Bi 58, pyrantel). According to observations made by Barski and Zasadowski (2006), residues of dimethoate (administered at a dose of $1 / 25 \mathrm{LD}_{50}$ for 28 days) were detected in rat livers up to the $2^{\text {nd }}$ day of the experiment. Similar observations were made for residues of pyrantel embonate (Zasadowski at al. 2006). The increased concentration of ascorbic acid could have also resulted from re-activation of enzymatic and non-enzymatic mechanisms of vitamin C synthesis (Banhegyi et al. 1997, 1998).

To summarize the results obtained, it can be concluded that changes in the content of reduced glutathione and concentration of vitamin $\mathrm{C}$ in liver of rats were determined not only by doses of the administered xenobiotics (pyrantel tartrate and dimethoate), but also by the manner of their application (single or combined intoxication). The administration of pyrantel tartrate before dimethoate (Bi 58 Nowy) only in some time intervals was found to reduce the intensity of changes evoked by the exclusive application of insecticide. Therefore, it can be presumed that not in all the cases of mixed intoxications, as shown in our study, intensification should be expected in changes of the indicators analyzed, which indicates the complexity of antioxidant mechanisms.

\section{Obsah glutathionu a vitamínu C v játrech krys vystavených účinku dimethoátu a pyrantel tartrátu}

Studie byla provedena za účelem zkoumání účinku p.o. podání dimethoátu (Bi 58 Nowy) a/nebo pyrantel tartrátu na koncentrace glutathionu (GSH) a vitamínu $\mathrm{C} v$ játrech krys. Krysám ze skupiny 1 byl podáván pyrantel tartrát $\mathrm{v}$ dávce $85 \mathrm{mg} \cdot \mathrm{kg}^{-1}$ živé váhy $\mathrm{v}$ dvoutýdenním intervalu, zatímco zvíratům ze skupiny 2 byl podáván Bi 58 Nowy (38\% dimethoát) v dávce $25 \mathrm{mg} \cdot \mathrm{kg}^{-1}$ živé váhy po 28 dní a zvíŕatům ze skupiny 3 byly podány obě látky způsobem uvedeným výše. Bylo zjištěno, že pyrantel tartrát zvýšil koncentraci glutathionu v játrech, zatímco koncentrace vitamínu $\mathrm{C}$ se pohybovala okolo kontrolních hodnot. Po 28denním podávání dimethoátu (Bi 58 Nowy) došlo s výjimkou 6. hodiny po aplikaci ke zvýšení koncentrace GSH, přičemž statisticky významné rozdíly byly po 3. a 14. dni. Koncentrace vitamínu $\mathrm{C} v$ jaterním homogenátu byla po podání dimethoátu ve srovnání $\mathrm{s}$ kontrolní hodnotou snížená až do 3. dne. Následně byl pozorován nárůst až do skončení experimentu. U zvírat, kterým byly podány obě látky, byly s výjimkou 7 . dne lehce snížené koncentrace vitamínu C. Podání pyrantel tartrátu před dimethoátem (Bi 58 Nowy) vedlo $\mathrm{k}$ redukci intenzity změn způsobených podáním insekticidu jen $\mathrm{v}$ některých časových intervalech. Výsledky mohou poukazovat na to, že ne ve všech prŕípadech kombinované intoxikace lze očekávat intenzivnější změny analyzovaných hodnot.

\section{References}

ABDOLLAHI M, MOSTAFALOU S, POURNOURMOHAMMADI S, SHADNIA S 2004: Oxidative stress and cholinesterase inhibition in saliva and plasma of rats following subchronic exposure to malathion. Comp Biochem Physiol C-Toxicol Pharmacol 137: 29-34

AHMED RS, SETH V, PASHA ST, BARENJEE BD 2000: Influence of dietary ginger (Zingiber officinalis Rosc.) on oxidative stress induced by malathion in rats. Food Chem Toxicol 38: 443-450

ALTUNTAS I, DELIBAS N, DEMIRCI M, KILINC I, TAMER N 2002: The effects of methidathion on lipid peroxidation and some liver enzymes: role of vitamins E and C. Arch Toxicol 76: 470-473

ALTUNTAS I, DELIBAS N, DOGUC DK, OZMEN S, GULTEKIN F 2003: Role of reactive oxygen species in organophosphate insecticide phosalone toxicity in erythrocytes in vitro. Toxicol In Vitro 17: 153-157

ALTUNTAS I, KILINC I, ORHAN H, DEMIREL R, KOYLU H, DELIBAS N 2004: The effects of diazinon on lipid peroxidation and antioxidant enzymes in erythrocytes in vitro. Hum Exp Toxicol 23: 9-13 
BANHEGYI G, BRAUN L, CSALA M, PUSKAS F, MANDL J 1997: Ascorbate metabolism and its regulation in animals. Free Radic Biol Med 23: 793-803

BANHEGYI G, BRAUN L, CSALA M, PUSKAS F, SOMOGYI A, KARDON T, MANDL J 1998: Ascorbate and environmental stress. Ann N Y Acad Sci 851: 292-303

BARSKI D, ZASADOWSKI A 2006: Residues of dimethoate in the liver and AchE activity in blood of rats after exposure to dimethoate, and dimethoate and pyrantel embonate. Pol J Vet Sci 9: 43-49

DRINGER R 2000: Metabolism and functions of glutathione in brain. Prog Neurobiol 62: 649-671

ELLMAN GL 1959: Tissue sulfhydryl groups. Arch Biochem Biophys 82: 70-7

FICEK W 1997: Biological importance of vitamin C in the bodies of mammals. Biochem Arch 13: 207-213

GOEL A, DANI V, DHAWAN DK 2005: Protective effects of zinc on lipid peroxidation, antioxidant enzymes and hepatic histoarchitecture in chlorpyrifos-induced toxicity. Chem Biol Interact 156: 131-140

GRIFFIN KA, JOHNSON CB, BREGER RK, FRANKLIN RB 1982: Effects of inducers and inhibitors of cytochrome P-450-linked monooxygenases on the toxicity, in vitro metabolism and in vivo irreversible binding of 2-methylonaphthalene in mice. J Pharmacol Exp Ther 221: 517-24

GRIFFIN KA, JOHNSON CB, BREGER RK, FRANKLIN RB 1983: Pulmonary toxicity of 2-methylnaphthalene: lack of the relationship between toxicity, dihydrodiol formation and irreversible binding to cellular macromolecules in DBA/2J mice. Toxicology 26: 213-30

IKEDA K, KUMAGAI Y, NAGANO Y, MATSUZAWA N, KOJO S 2003: Change in the concentration of vitamins $\mathrm{C}$ and $\mathrm{E}$ in rat tissues by paraquat administration. Biosci Biotechnol Biochem 67: 1130-1131

JEYARATNAM J 1990: Acute pesticide poisoning: A major global health problem. World Health Stat Q 43: 139-144

JOHN S, KALE M, RATHORE N, BHATNAGAR D 2001: Protective effect of vitamin E in dimethoate and malathion induced oxidative stress in rat erythrocytes. J Nutr Biochem 12: 500-504

KALENDER S, KALENDER Y, OGUTCU A, UZUNHISARCIKLI M, DURAK D, ACIKGOZ F 2004: Endosulfan-induced cardiotoxicity and free radical metabolism in rats: the protective effect of vitamin E. Toxicology 202: 227-235

LUIS 1997: Report for dimethoate and a review of the dimethoate file. Label Use Information System, November (1997)

ŁUKASZEWICZ-HUSSAIN A, MONIUSZKO-JAKONIUK J 2003: Organophosphate insecticide chlorfenvinphos affects enzymatic and nonezymatic antioxidants in erythrocytes and serum of rats. Pol J Environ Stud 12: 417-423

LYONS ET, TOLLIVER SC, RATHGEBER RA, COLLINS SS 2007: Parasite field study in central Kentucky on thoroughbred foals (born in 2004) treated with pyrantel tartrate daily and other parasiticides periodically. Parasitol Res 100: 473-478

MEISTER A 1992: On the antioxidant effects of ascorbic acid and glutathione. Biochem Pharmacol 44: 1905-1915

MOLYNEUX CA, GLYN MC, WARD BJ 2002: Oxidative stress and cardiac microvascular structure in ischemia and reperfusion: the protective effect of antioxidant vitamins. Microvasc Res 64: 265-277

NARAYANA K, PRASHANTHI N, NAYANATARAA, KUMAR H, ABHILASH K, BAIRY KL 2005: Effects of methyl parathion (o,o-dimethyl o-4-nitrophenyl phosphorothioate) on rat sperm morphology and sperm count, but not fertility, are associated with decreased ascorbic acid level in testis. Mutat Res 588: 28-34

PADH H 1991: Vitamin C: newer insights into its biochemical function. Nutr Rev 49: 65-70

PARKE DV 1991: Nutritional requirements for detoxication of environmental chemicals. Food Addit Contam 8: 381-396

PARKE DV, PIOTROWSKI JK 1996: Glutathione: its role in detoxication of reactive oxygen species and environmental chemicals. Acta Pol Toxicol 4: 1-14

PASTORE A, FEDERICI G, BERTINI E, PIEMONTE F 2003: Analysis of glutathione: implication in redox and detoxification. Clin Chim Acta 333: 19-39

PATRA RC, SWARUP D, DWIVEDI SK 2001: Antioxidant effects of $\alpha$-tocopherol, ascorbic acid and L-methionine on lead induced oxidative stress to the liver, kidney and brain in rats. Toxicology 162: 81-88

PRUETT PL 1996: Dimethoate Usage Report (5/30/96). U.S. Environmental Protection Agency

RAYES D, DE ROSA MJ, SPITZMAUL G, BOUZAT C 2001: The anthelminthic pyrantel acts as low efficacious agonist and an open-channel blocker of mammalian acetylcholine receptors. Neuropharmacology 41: 238-245

RUTKOWSKI M, GRZEGORCZYK K, GREGER J 2002: Adaptation of the phosphotungstate method for the determination of vitamin $C$ contents in animal and human tissues. Z Naturforsch 57 (C): 1062-1065

SAUBERLICH HE 1994: Pharmacology of vitamin C. Annu Rev Nutr 14: 371-391

SHARMA Y, BASHIR S, IRSHAD M, NAG TC, DOGRA TD 2005: Dimethoate-induced effects on antioxidant status of liver and brain of rats following subchronic exposure. Toxicology 215: 173-181

SIVAPIRIYA V, JAYANTHISAKTHISEKARAN, VENKATRAMAN S 2006: Effects of dimethoate (O,Odimethyl S-methyl carbamoyl methyl phosphoroditioatate) and ethanol in antioxidant status of liver and kidney of experimental mice. Pest Biochem Physiol 85: 115-121

SPODNIEWSKA A, ZASADOWSKI A 2006: The effect of dimethoate and pyrantel on vitamin C concentration in the rat liver. Pol J Vet Sci 9: 23-29 
STEENLAND K, JENKINS B, AMES RG, O’MALLEY M, CHRISLIP D, RUSSO J 1994: Chronic neurological sequelae to organophosphate pesticide poisoning. Am J Public Health 84: 731-736

STEENLAND K 1996: Chronic neurological effects of organophosphate pesticides. Br Med J 312: 1312-1213

SUNTRES ZE 2002: Role of antioxidants in paraquat toxicity. Toxicology 180: 65-77

VALDEZ RA, DIPIETRO JA, PAUL AJ, LOCK TF, HUNGERFORD LL, TODD KS 1995: Controlled efficiacy study of the bioequivalence of Strongid C and generic pyrantel tartrate in horses. Vet Parasitol 60: 83-102

WYSOCKI A, ZASADOWSKI A 2005: The effect of dimethoate and pyrantel embonate intoxication on selected elements of antioxidative barrier in rats. Acta Toxicol 13: 67-76

YARSAN E, CAKIR O 2006: Effects of dichlorvos on lipid peroxidation in mice on subacute and subchronic periods. Pest Biochem Physiol 86: 106-109

YARSAN E, TANYUKSEL M, CELIK S, AYDIN A 1999: Effect of aldicarb and malathion on lipid peroxidation. Bull Environ Contam Toxicol 63: 575-581

ZASADOWSKI A, BARSKI D, PIEKOSZEWSKI W 2006: Influence of dimethoate on pyrantel concentration in rat liver. Bull Vet Inst Puławy 50: 397-400 